\title{
FAKTOR-FAKTOR YANG MEMENGARUHI PARTISIPASI MASYARAKAT DALAM PENGANGGARAN DAN PENDAPATAN ASLI DESA
}

\author{
Zaenal Fanani \\ fanani@feb.unair.ac.id \\ Departemen Akuntansi Fakultas Ekonomi dan Bisnis Universitas Airlangga
}

\begin{abstract}
The purpose of this study was to examine the influence of village characteristics factors, leadership styles, political legitimacy, access to information, and village head motivation on community participation in village budgeting and to examine the effect of community participation in budgeting on village original revenues. The population of this study is the village head of all villages in East Java Province, the sample is 100 village heads. Data analysis techniques used to test the hypothesis using Structural Equation Modeling (SEM) with software Wrap-PLS 5.0. The result of the research shows that the factor of political legitimacy influences the motivation of village head, the character of the village influences the participation of the society in budgeting in the village. Factors of leadership style, political legitimacy, and access to information, have no effect on the village head's motivation. Factors of leadership style, political legitimacy, and access to information, and the motivation of village heads do not influence public participation in village budgeting. Public participation in budgeting has an effect on the original income of the village.
\end{abstract}

Key words: the determinants of public participation in budgeting, the original income of the village

\section{ABSTRAK}

Tujuan penelitian ini untuk menguji pengaruh faktor-faktor karakteristik desa, gaya kepemimpinan, legitimasi politik, akses informasi, dan motivasi kepala desa terhadap partisipasi masyarakat dalam penganggaran di desa dan menguji pengaruh partisipasi masyarakat dalam penganggaran terhadap pendapatan asli desa. Populasi penelitian ini adalah kepala desa dari seluruh desa yang ada di wilayah Propinsi Jawa Timur, sampelnya 100 kepala desa. Teknik analisa data yang digunakan untuk menguji hipotesis menggunakan Structural Equation Modelling (SEM) dengan software Wrap-PLS 5.0. Hasil penelitian menunjukkan faktor legitimasi politik berpengaruh terhadap motivasi kepala desa, karakteristik desa berpengaruh terhadap partisipasi masyarakat dalam penganggaran di desa. faktor gaya kepemimpinan, legitimasi politik, dan akses informasi, tidak berpengaruh terhadap motivasi kepala desa. Faktor gaya kepemimpinan, legitimasi politik, dan akses informasi, dan motivasi kepala desa tidak berpengaruh partisipasi masyarakat dalam penganggaran di desa. partisipasi masyarakat dalam penganggaran berpengaruh terhadap pendapatan asli desa.

Kata kunci: faktor penentu partisipasi masyarakat dalam penganggaran, pendapatan asli desa

\section{PENDAHULUAN}

Undang-Undang No 6 Tahun 2014 menjadi landasan formal dimulainya otonomi desa. Perubahan paling terlihat dalam UU Desa tersebut adalah pemberian kewenangan yang lebih besar pada Desa untuk mengelola dan membangun daerahnya sendiri, serta sebagai pengakuan kembali (recognition) keragaman karakter- istik desa oleh Negara sejak kebijakan homogenisasi dan sentralisasi bentuk desa di masa Orde Baru tahun 1979. Untuk melaksanakan kewenangannya tersebut, sesuai prinsip subsidiaritas yang diatur dalam UU Desa, Pemerintah berkewajiban mengalokasikan Dana Desa sebesar 10\% dari jumlah dana transfer ke daerah dalam APBN. Disamping itu, Pemerintah Daerah 
juga diwajibkan mengalokasikan $10 \%$ bagian dari dana transfer pemerintah pusat ke daerah, serta bagi hasil pajak dan retribusi daerah untuk ditransfer ke Desa dalam bentuk Alokasi Dana Desa (ADD). Dari simulasi perhitungan yang dibuat berdasar APBN 2014 dan APBD Kab/Kota Tahun 2014, jumlah anggaran yang akan diterima tiap desa rata-rata sebesar Rp.1.436.033. 121,00 (http://www.budimansudjatmiko. net). Angka tersebut relatif besar untuk tingkat Desa bila dibandingkan selama ini yang mayoritas bergantung dari anggaran ADD, dimana secara realita hanya residual dari anggaran daerah (APBD).

UU Desa mengamanatkan perlunya perubahan dalam tata kelola kekayaan (keuangan) Desa secara lebih modern dalam pengelolaan anggaran. Hal ini sejatinya bukanlah hal yang baru, mengingat sejak dikeluarkannya PP 79 Tahun 2005, tata kelola pemerintahan Desa telah diatur, termasuk didalamnya penerapan prinsip good governance atas pengelolaan keuangan desa. Yang membedakan hanya pada tekanan dan tuntutan yang lebih besar dari semua pihak sebagai konsekuensi peningkatan anggaran yang signifikan sebagaimana diatur dalam UU Desa. Desa diharapkan mampu menyusun anggaran, melaksanakan, dan mempertanggun jawabkan secara lebih akuntabel, transparan, dan partisipatif, dalam tujuannya untuk meningkatkan pemberdayaan dan kesejahteraan masyarakat dengan anggaran yang besar (Pratiwi, 2012; Sujito, 2013). Pemerintah Desa diharapkan mampu menciptakan sinergi dengan lembaga desa yang ada (BPD, LPM, Organisasi lokal desa lainnya) yang secara formal menjadi saluran partisipasi masyarakat.

Jumlah Desa di Indonesia yang sebanyak 72.944 Desa, dengan beragam corak dan karakteristiknya masing-masing dapat menjadi sebuah kekuatan yang besar untuk membangun Indonesia kedepan, bila UU Desa mampu dijalankan sebagaimana yang diharapkan. Namun disisi lain, keragaman yang ada juga berpotensi menjadi hambatan yang besar dalam pelaksanaan UU Desa, ketika karakteristik yang dimiliki Desa justru resisten dengan nilai-nilai baru diluar yang dianutnya selama ini. Eko (2012) membedakan ragam dan perkembangan desa di Indonesia menjadi empat corak, yaitu 1) Desa asli (indigenous village), dimana pengaruh adat jauh lebih kuat dibanding pengaruh faktor lain; 2) Desa parokhial, pengaruh agama atau kekerabatan telah merubah ciri desa asli menjadi dua bentuk desa: parokhialisme kekerabatan dan parokhialisme keagamaan; 3) Desa korporatis, merupakan bentuk desa yang paling mendominasi di Indonesia sebagai dampak UU No 5/1979 di masa orde baru; dan 4) Desa sipil (civil village), pengaruh dari luar (LSM maupun lembaga internasional) telah merubah corak desa menjadi institusi yang berorientasi pada pelayanan publik dan pemberdayaan masyarakat. Kondisi tersebut mengindikasikan bahwa ragam atau corak desa adalah faktor yang dapat memengaruhi pelaksanaan UU Desa, disamping kecukupan daya dukung sebagai prasyarat dalam mengimplementasikan UU tersebut. Hal itu akan nampak ketika proses perencanaan dan penyusunan anggaran (APBDes) berlangsung.

Salah satu prinsip pokok penyusunan APBDes dalam UU Desa adalah terbangunnya partisipasi masyarakat dalam penganggaran, pelaksanaan pembangunan, maupun dalam pengawasannya. Hal itu mengisyaratkan bahwa pendekatan penganggaran yang digunakan adalah buttom up. Model pendekatan tersebut bertujuan agar program dan kegiatan yang direncanakan benar-benar sesuai kebutuhan masyarakat setempat dalam upaya membangun kesejahteraannya. Banyaknya faktor yang memengaruhi tingkat partisipasi penganggaran sering menghasilkan efek yang beragam di masing-masing organisasi atau institusi. Terlebih ketika hal tersebut dikotomikan menurut karakteristik antara sektor publik dan privat. Penelitian mengenai partisipasi penganggaran di sektor publik kadang menjadi bias ketika variabel 
yang digunakan mengadopsi prediktor yang diterapkan di sektor privat, tanpa melakukan kontrol atas perbedaan karakteristik yang ada, maupun penyesuaian terhadap variabel yang digunakan.

Gaya kepemimpinan, asimetri informasi, sikap kerja, locus of control, kebutuhan akan prestasi, desentralisasi, komitmen organisasi, serta inovasi, sering digunakan sebagai variabel yang memengaruhi partisipasi penganggaran (Fauzi dan Haryanto, 2013; Kunwaviyah dan Syafruddin, 2010; Rahardjo, 2009; Wahyuningsih dan Pramuka, 2012; Yuen, 2007).

Hasil penelitian menunjukkan penganggaran yang melibatkan partisipasi anggota organisasi berhubungan positif dengan kinerja organisasi maupun managerial. Hal ini menjadi salah satu alasan berkembangnya pendekatan penganggaran partisipatif (buttom up) di sektor publik maupun privat. Namun demikian kompleksitas tujuan dan tanggungjawab di sektor publik (pemerintah) dibanding privat, menyebabkan perlunya pendekatan multidimensional dengan mempertimbangkan aspek lain di luar pendekatan ekonomi dalam membahas penganggaran partisipatif.

Sektor publik (pemerintah) tidak dapat dilepaskan dari aspek sosial dan politik. Sektor ini memiliki konsekuensi pentingnya mengidentifikasi adanya pengaruh variabel lain, yang dimungkinkan berpengaruh terhadap partisipasi penganggaran. Eko (2012) menemukan bahwa kehidupan di Desa begitu kental dengan konteks village politic yang ada di dalamnya, dimana hampir setiap permasalahan masyarakat dan pembangunan desa akan bermuara pada kepala desa. Pendapat ini setidaknya telah memberi contoh bahwa sektor publik, terlebih pada tataran desa tidak terlepas dari aspek sosial yang tersirat dari kuatnya kepercayaan masyarakat desa kepada pemimpinnya, dan disisi lain hal itu menunjukkan bahwa kepala desa memiliki legitimasi yang kuat secara politis. Kondisi tersebut relevan dengan pendapat yang mengatakan bahwa penganggaran adalah politik, karena ini berhubungan dengan distribusi sumber daya dan membuat pilihan rencana alternatif untuk operasi pemerintah $(\mathrm{Wu}$ dan Wang, 2011). Dengan kata lain, penganggaran publik berkaitan erat dengan kepentingan publik dan kesejahteraan sosial, serta hubungan negara-masyarakat. Oleh karena itu, anggaran pemerintah memainkan peran penting dalam mengurangi ketidakpuasan sosial dan mengkonsolidasikan legitimasi Negara.

Liao dan Zhang (2012) dengan mempertimbangkan faktor lingkungan dan politik, menggunakan mekanisme keterlibatan interaktif dan dukungan politik sebagai prediktor partisipasi masyarakat dalam pengganggaran yang juga dimoderasi oleh motivasi (niat) manager kota. Partisipasi masyarakat dalam penganggaran dibagi kedalam 3 dimensi, yaitu komunikasi publik, konsultasi publik, serta dialog dan negosiasi publik. Penelitian tersebut membuktikan bahwa kedua prediktor yang digunakan berhubungan positif dengan ketiga dimensi partisipasi masyarakat dalam penganggaran. Sebelumnya Zhang dan Yang (2009) juga menemukan bahwa lingkungan politik yang relatif stabil, dan sikap manager (walikota) terhadap masukan warga merupakan faktor penting yang menjelaskan proses penganggaran partisipatif. Selain itu, Vincent (2010) dalam studi kasusnya menemukan bahwa penganggaran partisipatif hanya akan bersifat simbolik ketika didasarkan kepentingan politik lokal, namun sebaliknya dorongan kolektif masyarakat yang terlembaga dalam komunitas bisa menjadi bentuk organik dan relevan untuk penganggaran partisipatif.

Dimensi ketiga dari partisipasi masyarakat yang digunakan Liao dan Zhang (2012), yaitu dialog dan negosiasi publik, dalam konteks pemerintahan Desa termanifestasi dalam wujud musyawarah Desa. UU Desa mengatur bagaimana mekanisme dan kapan musyawarah Desa harus dilaksanakan. Dimensi dialog dan negosiasi publik tersebut menyiratkan bahwa mekanisme interaktif atau model komunikasi 
yang harusnya dibangun Pemerintah adalah komunikasi dua arah. Untuk mampu membangun model komunikasi tersebut, maka akses informasi yang memadai menjadi prasyarat penting. Atau dengan kata lain, akses informasi dimungkinkan juga memengaruhi partisipasi masyarakat. Bagi desa-desa yang telah maju, dengan daya dukung insfrastruktur yang memadai tentunya memudahkan Pemerintah Desa dalam menyampaikan informasi, maupun bagi masyarakat dalam memberikan umpan balik sebagai wujud keterlibatannya, namun tidak demikian halnya dengan desa-desa yang belum atau kurang terjangkau pembangunan. Akses informasi tidak hanya diartikan dalam bentuk saluran formal seperti pengumuman yang terpasang di papan, media cetak maupun elektronik, atau mungkin jaringan internet (website). Di Desa sering mekanisme informal jauh lebih efektif dalam mengakomodasi partisipasi warga. Kondisi itu tidak dapat dipisahkan dari karakteristik geografis, sosial, maupun demografi masyarakatnya. Berdasar penjelasan tersebut, dalam penelitian ini akses informasi menjadi salah satu prediktor yang dimungkinkan berpengaruh terhadap partisipasi masyarakat dalam penganggaran.

UU Desa mengatur bahwa selain dari Dana Desa yang dianggarkan melalui APBN, dan bagi hasil Pajak dan retribusi maupun ADD dari Pemda, Desa diharapkan juga mampu menggali sumber-sumber pendapatan asli desa (PADesa). Sumber Pendapatan Asli Desa diantaranya dari hasil usaha, pemanfaatan asset desa, dari swadaya atau partisipasi, gotong royong, maupun lain-lain yang sah (pasal 72 UU No 6/2014). Hal itu bertujuan untuk mendorong kemandirian Desa serta mempercepat pembangunan dan meningkatkan pemberdayaan masyarakat desa. Dengan membangun partisipasi masyarakat desa dalam proses penganggaran, maka diharapkan selain lebih mampu mengidentifikasi pemenuhan barang publik yang dibutuhkan masyarakat setempat, juga akan meningkatkan partisipasi yang lebih nyata dalam bentuk tenaga maupun materi. Hal ini didukung bukti empiris yang menunjukkan bahwa dimensi modal sosial yakni jaringan sosial dan solidaritas berhubungan positif dengan sumbangan sukarela dalam penyediaan barang publik (Leonard, Croson, dan Oliveira, 2010; Valastro, 2012). Mengacu realita yang ada bahwa pada dasarnya desa memiliki modal sosial yang kuat (Handayani, Syafrudin, dan Eko, 2012), maka dengan partisipasi masyarakat yang tinggi dalam proses penganggaran, diharapkan akan berkontribusi positif terhadap pendapatan swadaya atau gotong royong sebagai bagian Pendapatan Asli Desa.

Penelitian ini berbeda dari penelitian penelitian sebelumnya. Pertama, penelitian ini menggunakan variabel yang lebih kontekstual untuk sektor publik, dengan menambahkan beberapa predictor diluar pendekatan ekonomi ataupun akuntansi keperilakuan, yaitu variabel karakteristik desa dan dukungan politik. Selain itu penggunaan variabel akses informasi, secara substansi berbeda dengan asimetri informasi (Fauzi dan Haryanto, 2013). Akses informasi lebih menekankan pada tersedianya saluran informasi yang memadai sebagai jembatan komunikasi dan aktualisasi masyarakat dengan pemerintah desa, hal ini lebih relevan untuk tingkat desa atau pemerintah lokal. Dengan menambah beberapa variabel baru, diharapkan dapat memperbaiki kesenjangan penelitian terkait partisipasi penganggaran di sektor publik yang kurang mempertimbangkan pengaruh aspek politik dan sosial, serta karaktersitik obyek. Hal tersebut sekaligus menjadi motivasi dalam penelitian ini.

Kedua, penelitian ini tidak membedakan pengaruh variabel bebas terhadap masing-masing dimensi partisipasi penganggaran (Liao dan Zhang, 2012), yakni dimensi komunikasi publik, konsultasi publik, serta dialog dan negosiasi publik. Hal ini dilakukan karena dimensi partisipasi masyarakat dalam penganggaran yang ada di desa secara mandatory melalui musyawarah desa (dimensi dialog dan 
negosiasi publik), sehingga efek yang ditimbulkan adalah dikotomi antara partisipasi dalam arti sesungguhnya (nyata) atau hanya akan bersifat semu atau simbolik ketika motif politis dari Pemerintah Desa lebih menonjol (Vincent, 2010; Wu dan Wang, 2011). Berpedoman pada asumsi tersebut, maka kedua dimensi lainnya dapat di- artikan sebagai proses menuju dimensi dialog dan negosiasi publik.

Ketiga, penelitian ini mengaitkan partisipasi penganggaran dengan implikasi ekonomis yaitu pendapatan asli desa, berbeda dengan kebanyakan penelitian selama ini yang banyak mengaitkan partisipasi penganggaran di sektor publik dengan kinerja manajerial (Rahardjo, 2009; Wahyuningsih dan Pramuka, 2012; Yuen, 2007). Hal ini lebih kontekstual dan dimungkinkan untuk level Desa, mengingat dalam UU Desa salah satu sumber pendapatan asli desa diperoleh dari pendapatan swadaya atau gotong royong. Partisipasi masyarakat yang tinggi untuk ikut terlibat dalam penganggaran, diharapkan akan berkontribusi positif terhadap pendapatan swadaya atau gotong royong. Leonard et al., (2010) dan Valastro (2012) menyatakan bahwa jaringan sosial dan solidaritas berhubungan positif dengan sumbangan sukarela (waktu, tenaga, dan materi) atas pemenuhan barang publik, menjadi kerangka logis yang mendasari premis tersebut. Fokus penelitian ini menguji faktor-faktor yang memengaruhi partisipasi masyarakat dalam penganggaran di Desa. Permasalahan dalam penelitian ini dapat dirumuskan sebagai berikut 1) apakah faktor-faktor karakteristik desa, gaya kepemimpinan, legitimasi politik, akses informasi, dan motivasi kepala desa memengaruhi partisipasi masyarakat dalam penganggaran di desa? dan apakah partisipasi masyarakat dalam penganggaran berpengaruh terhadap pendapatan asli desa?

\section{TINJAUAN TEORETIS}

\section{Partisipasi Penganggaran}

Hampir setiap organisasi, terlepas dari ukuran, kompleksitas atau sektor usahanya, sangat bergantung pada anggaran dan sistem penganggaran untuk mencapai tujuan strategis. Keberhasilan dan pentingnya penganggaran berkaitan dengan identifikasi organisasi tujuan, alokasi tanggung jawab untuk mencapai tujuan-tujuan tersebut, dan akibat dari pelaksanaannya (Raghunandan, Ramgulam, dan Raghunandan, 2012). Dalam proses penganggaran diyakini adanya aspek teknis dan perilaku yang dapat menguntungkan organisasi dipahami jika kedua aspek tersebut dikelola dan terkoordinasi dengan benar. Aspek teknis penganggaran berkaitan dengan perhitungan matematis biaya dan pengeluaran yang diproyeksikan. Sedangkan aspek perilaku berfokus pada kemampuan untuk mencapai aspek teknis penganggaran de ngan memanfaatkan anggota organisasi tersebut. Dari pendapat tersebut Raghunandan et al., (2012) mengenalkan tiga macam pendekatan penganggaran, yaitu: 1) top down yang lebih dekat dengan gaya kepemimpinan otokratis; 2) buttom up dimana kepemimpinan demokratis lebih menonjol, sehingga lebih melibatkan partisipasi karyawan; 3) anggaran dinegosiasikan, yang merupakan perpaduan kedua anggaran sebelumnya (top-down dan buttom-up).

Tren penerapan penganggaran partisipatif (buttom up) yang makin berkembang luas di sektor publik (pemerintahan) secara tidak langsung menunjukkan meningkatnya keinginan pemerintah untuk melibatkan masyarakat dalam pengambilan keputusan dan kebijakan publik. Wu dan Wang (2011) menyatakan bahwa penganggaran partisipatif adalah proses pengambilan keputusan kreatif yang melibatkan warga untuk memutuskan atau membantu memutuskan bagaimana menangani pemakaian sumber daya publik. Namun bagaimana mekanisme partisipasi warga masyarakat dalam penganggaran berbeda antar tingkatan pemerintahan, maupun antar Negara. Hal itu berkait erat dengan regulasi yang ada maupun model pengadopsian penganggaran partisipatif yang umumnya disesuaikan dengan karakteristik masing-masing peme- 
rintahan (Negara). Secara umum, pendapat yang mendukung penganggaran partisipatif menyatakan bahwa manfaat yang dihasilkan dari pendekatan penganggaran partisipatif antara lain: memberi kesempatan warga masyarakat untuk berperan dalam mengalokasikan sumber daya, lebih dapat memprioritaskan program kebijakan sosial, serta mengawasi penggunaan pembelanjaan publik. Yang pada akhirnya akan membantu untuk menambah bentuk kontrol sosial masyarakat sipil, di samping adanya kontrol anggaran, serta meningkatkan akuntabilitas keuangan pemerintah.

Mekanisme partisipasi penganggaran di Desa sesuai regulasi yang ada adalah melalui Musyawarah Desa sebagai lembaga kekuasaan tertinggi di Desa. dapat dipersamakan dengan dimensi dialog dan negosiasi publik (Liao dan Zhang, 2012), sedangkan dimensi komunikasi publik dan konsultasi publik dapat diartikan sebagai proses yang terjadi menuju dimensi dialog dan negosiasi publik. Pihak yang berperan penting dalam menyelenggarakan Musyawarah Desa adalah BPD. Selain itu UU No 6/2014 mengatur bahwa para pihak yang wajib dilibatkan dalam Musyawarah Desa meliputi Pemerintah Desa, BPD, LPM, semua organisasi Kemasyarakatan lain baik yang formal maupun non-formal (ormas kepemudaan, Lansia, kelompok perempuan), RT/RW, serta perwakilan tokoh masyarakat. Banyaknya pihak yang terlibat dimaksudkan agar proses penganggaran tersebut mampu mengidentifikasi dengan baik kebutuhan seluruh kelompok masyarakat tanpa memandang diskriminasi mayoritas dan minoritas. Disini BPD menjadi aktor kunci dalam menjembatani keterlibatan warga dengan pemerintah desa, serta menjamin bahwa penganggaran yang disusun telah mengakomodir kebutuhan masyarakat akan pemenuhan barang publik, dan sebagai upaya pemberdayaan masyarakat. Yang perlu diperhatikan adalah munculnya partisipasi semu (simbolik) sebagai dampak negatif penganggaran partisipatif dimana motivasi yang melandasinya hanya untuk membangun legitimasi politik dari sebuah rezim pemerintahan yang korup, serta mempromosikan tujuan-tujuan politiknya sendiri (Vincent, 2010). Dalam kondisi tersebut penganggaran partisipatif telah diatur sedemikian rupa seolah-olah menggambarkan bagaimana proses yang berlangsung dihasilkan dari inisiatif dan pengambilan keputusan yang demokratis. Selain itu dalam konsteks pemerintahan Desa perlu juga diperhatikan kuatnya pengaruh patronklien antara kepala Desa dengan masyarakatnya yang berakibat praktik partisipasi yang berlangsung hanya prosedural semata (Mahendro, 2013).

\section{Pengaruh Karakteristik Desa terhadap Partisipasi Masyarakat dalam Pengang- garan}

Suroso, Hakim, dan Noor (2014) membuktikan bahwa faktor internal (struktur demografi masyarakat) yang merupakan salah satu bentuk karakteristik desa berpengaruh terhadap partisipasi masyarakat dalam proses Musrembangdes. Sementara itu Eko (2012) dalam studi kasusnya menemukan bahwa ragam corak desa dapat menunjukkan perkembangan kemajuan suatu desa. Semakin maju corak perkembangan sebuah Desa dapat diartikan bahwa tingkat pemenuhan dan akses atas barang kebutuhan publik juga makin memadai. Hal itu dimungkinkan juga akan memengaruhi partisipasi penganggaran karena terkait dengan tingkat kedasaran masyarakat untuk kemudian aktif terlibat dalam mengidentifikasi kebutuhan mendasar yang belum dipenuhi, sekaligus ikut serta dalam pengambilan keputusan publik. Merujuk uraian tersebut, dapat dirumuskan hipotesis sebagai berikut:

$\mathrm{H}_{1}$ : Karakteristik Desa berpengaruh terhadap Partisipasi Penganggaran

Pengaruh Gaya Kepemimpinan terhadap Motivasi Kepala Desa dan Partisipasi Masyarakat dalam Penganggaran

Gaya kepemimpinan yang sesuai kebutuhan organisasi, diyakini akan me- 
ningkatkan partisipasi dan motivasi pimpinan maupun anggota organisasi, sehingga dapat meningkatkan kinerjanya maupun kepuasan individu dan kolektif. Namun dari beberapa penelitian masih menunjukkan hasil yang beragam atas pengaruh gaya kepemimpinan dengan partisipasi penganggaran. Fauzi dan Haryanto (2013) membuktikan bahwa Gaya kepemimpinan tidak berhubungan positif dengan partisipasi penganggaran. Demikian juga Ketika model konstruk tersebut diubah, gaya kepemimpinan juga tidak memberikan efek pengaruh moderasi terhadap hubungan partisipasi penganggaran dengan kinerja manajerial (Rahardjo, 2009). Namun hasil berbeda ditunjukkan Suroso et al. (2014), yang membuktikan bahwa kepemimpinan justru berhubungan positif dengan tingkat partisipasi masyarakat dalam proses perencanaan dan penganggaran (Musrembangdes). Demikian pula Zhang dan Yang (2009) membuktikan bahwa model kepemimpinan demokratis yang dibentuk oleh pengetahuan dan ketrampilan professional berhubungan positif dengan motivasi pimpinan yang lebih besar untuk melibatkan warga. Menyandarkan pada uraian tersebut, dapat dirumuskan hipotesis sebagai berikut:

$\mathrm{H}_{2 \mathrm{a}}$ : Gaya Kepemimpinan berpengaruh positif terhadap Motivasi kepala desa.

$\mathrm{H}_{2 b}$ : Gaya Kepemimpinan berpengaruh positif terhadap Partisipasi masyarakat dalam Penganggaran

\section{Pengaruh Legitimasi Politik terhadap Motivasi Kepala Desa dan Partisipasi Masyarakat dalam Penganggaran}

Penganggaran publik berhubungan erat dengan kepentingan publik, instrument mencapai kesejahteraan sosial, serta terkait hubungan Negara dan masyarakat. Oleh karena itu, anggaran memainkan peran penting dalam mengurangi ketidakpuasan sosial dan mengkonsolidasikan legitimasi Pemerintah (Wu dan Wang, 2011). Secara empiris, pendapat tersebut telah dibuktikan (Liao dan Zhang, 2012; Zhang dan Yang,
2009), bahwa dukungan (legitimasi) politik linier dengan dorongan atau motivasi manager (walikota) untuk melibatkan masyarakat dalam penganggaran maupun partisipasi masyarakat itu sendiri. Legitimasi politik berkaitan dengan tingkat kepercayaan dan dukungan masyarakat kepada Pemerintah (kepala desa). Ketika legitimasi politik pemerintah (kepala desa) menurun, hal tersebut akan menurunkan keterlibatan masyarakat dalam setiap program atau kegiatan pemerintahan desa, sebagai akibat hilangnya kepercayaan dan dukungan masyarakat kepada pemerintah (Ekawati, 2012). Berdasar uraian tersebut, dapat dirumuskan hipotesis sebagai berikut: $\mathrm{H}_{3 a}$ : Legitimasi politik berpengaruh positif terhadap motivasi kepala desa

$\mathrm{H}_{3 b}$ : Legitimasi politik berpengaruh positif terhadap Partisipasi masyarakat dalam Penganggaran

\section{Pengaruh Akses Informasi terhadap Motivasi Kepala Desa dan Partisipasi Masyarakat dalam Penganggaran}

Kecukupan saluran atau akses informasi akan berpengaruh terhadap pola (model) komunikasi yang berlangsung. Penganggaran partisipatif yang menggunakan pendekatan buttom up mensyaratkan pola komunikasi dua arah, antara anggota organisasi dengan pimpinan (manager), atau dalam sektor publik antara masyarakat dengan pemerintah. Liao dan Zhang (2012) menyatakan bahwa mekanisme komunikasi yang diciptakan pemerintah setempat memengaruhi keberhasilan partisipasi penganggaran. Dengan mekanisme komunikasi dua arah, warga bisa meminta informasi yang mereka butuhkan, mengartikulasikan posisi mereka sendiri, memberikan umpan balik terbuka, dan memahami kendala yang dihadapi oleh masyarakat. Dengan kata lain, mekanisme komunikasi tersebut dapat dipersamakan dengan kecukupan akses informasi yang tersedia baik dalam bentuk formal maupun informal. Terlebih bila populasi desa cukup besar, menjadi sebuah 
keniscayaan penggunaan media lokal untuk memastikan informasi tentang proses partisipasi dapat mencapai sebagian besar penduduk (Zhang dan Yang, 2009). Merujuk uraian tersebut, dapat dirumuskan hipotesis sebagai berikut:

$\mathrm{H}_{4 a}$ : Akses informasi berpengaruh positif terhadap motivasi kepala desa

$\mathrm{H}_{4 b}$ : Akses informasi berpengaruh positif terhadap Partisipasi masyarakat dalam Penganggaran

Pengaruh Motivasi kepala desa terhadap Partisipasi Masyarakat dalam Penganggaran

Liao dan Zhang (2012) menyatakan bahwa dorongan atau motivasi manajer kota untuk melibatkan warga berhubungan positif dengan partisipasi warga dalam penganggaran. Pendapat senada sebelumnya telah dinyatakan Zhang dan Yang (2009), bahwa sikap manajer kota terhadap warga partisipasi mungkin adalah prediktor yang paling penting dari keputusan keterlibatan warga dalam penganggaran. Merujuk kedua temuan empiris tersebut, dapat dirumuskan hipotesis sebagai berikut: $\mathrm{H}_{5}$ : Motivasi kepala desa untuk melibatkan masyarakat berpengaruh positif terhadap Partisipasi masyarakat dalam Penganggaran

\section{Pengaruh Partisipasi Masyarakat dalam Penganggaran Terhadap Pendapatan Asli Desa}

Salah satu sumber PADesa berasal dari pendapatan swadaya, partisipasi, atau gotong royong. Tetapi dalam praktik, sejatinya ada permasalahan mendasar terkait pengelolaan pendapatan swadaya atau partisipasi atau gotong royong, hal ini disebabkan belum adanya ketentuan atau standart yang mengatur perlakuan (pengakuan, pengukuran, pelaporan) atas pendapatan tersebut. Namun permasalahan tersebut tidak menjadi aspek kajian dalam penelitian ini. Yang menjadi perhatian adalah, dengan partisipasi masyarakat yang tinggi untuk ikut terlibat dalam peng- anggaran, diharapkan akan berkontribusi positif terhadap pendapatan swadaya atau gotong royong. Selain itu disisi lain, hasil dari pendapatan swadaya, partisipasi, atau gotong royong pada dasarnya dapat dihubungkan atau mengindikasikan tingkat partisipasi masyarakat dalam proses penganggaran maupun pelaksanaan pembangunan. Pendapat ini sejalan dengan temuan Leonard et al. (2010) yang membuktikan bahwa jaringan sosial yang lebih besar akan meningkatkan kesadaran seseorang atas kebutuhan masyarakat yang pada akhirnya mendorong kontribusi sosial yang lebih besar. Sifat kasualitas antara partisipasi penganggaran dengan Pendapatan Asli Desa (swadaya atau partisipasi atau gotong royong) itulah yang menjadi fokus penelitian ini. Merujuk uraian tersebut, dapat dirumuskan hipotesis sebagai berikut:

$\mathrm{H}_{6}$ : Partisipasi Penganggaran berpengaruh positif terhadap Pendapatan Asli Desa

\section{METODE PENELITIAN Jenis Penelitian}

Jenis penelitan ini adalah explanatory, yaitu penelitian yang bertujuan untuk menguji suatu teori atau hipotesis guna memperkuat atau bahkan menolak teori atau hipotesis hasil penelitian yang sudah ada.

\section{Populasi dan Sampel, Teknik Peng- ambilan Sampel, Metode Pengumpulan Data}

Populasi dalam penelitian ini adalah kepala desa dari seluruh desa yang ada di wilayah Propinsi Jawa Timur. Sampelnya 100 kepala desa. Sampel dipilih dengan teknik purposive sampling yaitu pengambilan sampel berdasarkan kriteria atau pertimbangan tertentu. Kriteria atau pertimbangan yang digunakan: kepala desa dipilih karena pemegang otoritas dan penanggungjawab Pemerintah Desa.

Penelitian ini menggunakan data primer yang bersumber dari jawaban respon den atas pernyataan yang berhubungan dengan karakteristik desa, gaya kepemimpi- 
nan, legitimasi politik, akses informasi, motivasi kepala desa, partisipasi masyarakat dalam penganggaran di desa dan pendapatan asli desa. Untuk pengumpulan data menggunakan kuesioner yang didistribusikan langsung oleh peneliti kepada responden. Jumlah kuesioner yang didistribusikan sebanyak 120 kuesioner dengan tingkat pengembalian sebanyak 108 kuesioner dan yang dapat diolah sebanyak 100 kuesioner, untuk lebih jelasnya terkait pengumpulan data maka dapat dilihat pada Tabel 1 sebagai berikut:

Tabel 1

Penyebaran dan Pengembalian Kuesioner

\begin{tabular}{clc}
\hline \hline No & \multicolumn{1}{c}{ Uraian } & Jumlah \\
\hline 1 & $\begin{array}{l}\text { Kuesioner yang didistri- } \\
\text { busikan }\end{array}$ & 120 \\
2 & $\begin{array}{l}\text { Kuesioner yang tidak kem- } \\
\text { bali }\end{array}$ & 12 \\
3 & $\begin{array}{l}\text { Kuesioner yang kembali } \\
(1-2)\end{array}$ & 108 \\
4 & $\begin{array}{l}\text { Kuesioner yang kembali } \\
\text { tetapi tidak lengkap }\end{array}$ & 8 \\
5 & $\begin{array}{l}\text { Kuesioner yang dapat di- } \\
\text { olah (3-4) }\end{array}$ & 100 \\
\hline
\end{tabular}

Sumber: data hasil penelitian (diolah)

\section{Operasionalisasi dan Pengukuran Variabel Karakteristik Desa}

Karakteristik desa adalah perwujudan atau kesatuan geografi, sosial, ekonomi, politik dan kultural yang terdapat di situ (suatu daerah) dalam hubungannya dan pengaruhnya secara timbal balik dengan daerah lain (Eko, 2012). Pengukuran variabel karakteristik desa menggunakan 7 indikator.

\section{Gaya Kepemimpinan}

Gaya kepemimpinan adalah orientasi hubungan (consideration), cenderung menjalin hubungan baik antara atasan dengan anggota organisasi (bawahan), yang didasarkan hubungan saling menguntungkan, menghormati, serta saling mendukung (Fauzi dan Haryanto, 2013). Pengukuran gaya kepemimpinan menggunakan 5 indikator.

\section{Legitimasi Politik}

Legitimasi politik adalah kuatnya kepercayaan dan dukungan politik kepada pemerintah. Dukungan (legitimasi) politik linier dengan dorongan atau motivasi pemerintah untuk melibatkan masyarakat dalam penganggaran (Liao dan Zhang, 2012; Zhang dan Yang, 2009). Pengukuran variabel legitimasi politik menggunakan 4 indikator

\section{Akses Informasi}

Akses informasi adalah ketercukupan media untuk menyalurkan arus informasi dan model komunikasi yang terbentuk. Akses informasi tidak terbatas pada media formal namun juga meliputi media informal mengingat media tersebut lebih efektif dan umum diterima oleh sebagian besar masyarakat desa. Pengukuran variabel akses informasi menggunakan 4 indikator.

\section{Motivasi Kepala Desa}

Motivasi kepala desa adalah latar belakang dan sikap dari peran kepala Desa dalam mendorong partisipasi masyarakat. Manager lebih cenderung menggunakan berbagai strategi untuk mengatasi kompleksitas politik dan mengelola sumber daya organisasi, atau pula mempertahankan antusiasme mereka dan memotivasi anggota organisasi untuk berinisiatif ikut terlibat (Liao dan Zhang, 2012). Pengukuran variabel Motivasi kepala desa menggunakan 6 indikator.

\section{Partisipasi Masyarakat dalam Pengang- garan}

Partisipasi masyarakat dalam penganggaran adalah proses pembuatan kebijakan yang inovatif, dimana masyarakat dilibatkan secara langsung dalam pembuatan anggaran (Liao dan Zhang, 2012). Pengukuran variabel partisipasi masyarakat dalam penganggaran menggunakan 4 indikator. 


\section{Pendapatan Asli Desa}

Pendapatan asli desa adalah pendapatan yang berasal dari hasil usaha, hasil aset, swadaya dan partisipasi, gotong royong, dan lain-lain pendapatan asli Desa. Pengukuran variabel karakteristik desa menggunakan 4 indikator

Semua variabel diukur dengan menggunakan skala likert dengan lima poin (mulai dari 1 yang berarti (lemah) tidak memengaruhi, sampai 5 yang berarti (kuat) sangat memengaruhi hubungan).

\section{Teknik Pengumpulan Data}

Pengumpulan data dilakukan dengan menggunakan metode survey, dengan mengirim kuesioner kepada subjek penelitian, yaitu responden kepala desa. Kuesioner diberikan saat kepala desa mengikuti diklat pengembangan kapasitas SDM di Badan Diklat Balongsari Tama Surabaya.

\section{Teknik Pengujian Hipotesis}

Teknik analisis yang digunakan dalam penelitian ini adalah analisis Structural Equation Modelling (SEM). Adapun persamaan regresi analisis jalur adalah sebagai berikut:

$\mathrm{Y}_{1}=\beta 1 \mathrm{X} 2+\beta 2 \mathrm{X} 3+\beta 3 \mathrm{X} 4+\mathrm{e} 1$

$\mathrm{Y}_{2}=\beta 4 \mathrm{X} 1+\beta 5 \mathrm{X} 2+\beta 6 \mathrm{X} 3+\beta 7 \mathrm{X} 4+\beta 8 \mathrm{Y} 1+\mathrm{e} 2$ $\mathrm{Y}_{3}=\beta 9 \mathrm{Y} 2+\mathrm{e} 3$

\section{Keterangan}

$\mathrm{X}_{1}=$ Karakteristik Desa

$\mathrm{X}_{2}=$ Gaya Kepemimpinan

$\mathrm{X}_{3}=$ Legitimasi Politik

$\mathrm{X}_{4}=$ Akses Informasi

$\mathrm{Y}_{1}=$ Motivasi Kepala Desa

$\mathrm{Y}_{2}=$ Partisipasi Masyarakat dalam

Penganggaran

$\mathrm{Y}_{3}=$ Pendapatan Asli Desa

$\beta=$ Koefisien regresi yang distandarisasi

$\mathrm{e}=$ Error (faktor kesalahan)

Pengujian hipotesis dilakukan dengan menggunakan tingkat signifikansi maksimal $(a)=0,1$ atau $10 \%$. Untuk menguji hipotesis Jika nilai signifikansi < 0,1 (10\%) dan koefisien sama maka disimpulkan hipotesis tidak dapat ditolak.

\section{ANALISIS DAN PEMBAHASAN Hasil Penelitian}

Fokus dalam penelitian ini adalah untuk menguji pengaruh faktor-faktor karakteristik Desa, gaya kepemimpinan, legitimasi politik, akses informasi, dan Motivasi kepala desa terhadap partisipasi masyarakat dalam penganggaran di Desa dan menguji pengaruh partisipasi masyarakat dalam penganggaran terhadap Pendapatan Asli Desa. Fokus tersebut memposisikan partisipasi masyarakat dalam penganggaran di Desa dan Motivasi kepala desa sebagai variabel intervening. Untuk pengujian hipotesis telah menggunakan Structural Equation Modelling (SEM), lebih tepatnya menggunakan Variance-Based SEM atau Partial Least Squares (SEM-PLS) karena dalam SEM-PLS dapat digunakan secara efisien meskipun dengan ukuran sampel yang kecil dan dengan model yang komplek, sedangkan software yang digunakan dalam penelitian ini adalah Wrap-PLS 5.0. Dalam tahapan SEM-PLS akan mengestimasikan model pengukuran (measurement model) dan model struktural (structural model). Pada model pengukuran dilakukan evaluasi hubungan antara indikator dan konstruknya dengan menilai reliabilitas dan validitas sedangkan model struktural adalah spesifikasi hubungan antar variabel.

\section{Hasil Pengumpulan Data \\ Statistik Diskriptif Variabel Penelitian}

Statistik diskriptif adalah statistik yang digunakan untuk menganalisa data dengan cara mendiskripsikan atau menggambarkan data yang telah terkumpul sebagaimana adanya tanpa bermaksud membuat simpulan yang berlaku untuk umum atau generalisasi (Sugiyono, 2014). Adapun statistik diskriptif dalam penelitian ini akan memaparkan antara lain nilai maksimun, minimum, rata-rata, dan standar deviasi pada variabel-variabel penelitian, berdasarkan uji statistik yang dilakukan maka diperoleh 
hasil pada Tabel 2. Berdasarkan hasil analisis diskriptif Tabel 2 maka dapat disimpulkan semua variabel memiliki ratarata yang cukup besar yaitu karakteristik desa $(3,4925)$, gaya kepemimpinan $(4,226)$, legitimasi politik $(4,146)$, akses informasi $(3,8575)$, motivasi kepala desa $(4,394)$, partisipasi masyarakat dalam penganggaran $(4,0025)$, dan pendapatan asli desa $(3,66)$.

Tabel 2

Tabel Statistik Diskriptif

\begin{tabular}{|c|c|c|c|c|c|}
\hline Variabel & Indikator & Minimal & Maksimal & Modus & $\begin{array}{l}\text { Standar } \\
\text { Deviasi }\end{array}$ \\
\hline \multirow[t]{4}{*}{ Karakteristik Desa $\left(X_{1}\right)$} & $\mathrm{X}_{11}$ & 1,00 & 5,00 & 4,00 & 1,21256 \\
\hline & $\mathrm{X}_{12}$ & 1,00 & 5,00 & 4,00 & 1,14398 \\
\hline & $\mathrm{X}_{13}$ & 1,00 & 5,00 & 2,00 & 1,30252 \\
\hline & $\mathrm{X}_{14}$ & 1,00 & 5,00 & 5,00 & 0,93954 \\
\hline \multirow[t]{10}{*}{ Gaya Kepemimpinan $\left(X_{2}\right)$} & $X_{21}$ & 1,00 & 5,00 & 5,00 & 0,69311 \\
\hline & $X_{22}$ & 3,00 & 5,00 & 5,00 & 0,55949 \\
\hline & $X_{23}$ & 2,00 & 5,00 & 4,00 & 0,66332 \\
\hline & $X_{24}$ & 2,00 & 5,00 & 4,00 & 0,55268 \\
\hline & $X_{25}$ & 2,00 & 5,00 & 4,00 & 0,75338 \\
\hline & $\mathrm{X}_{26}$ & 2,00 & 5,00 & 4,00 & 0,68490 \\
\hline & $X_{27}$ & 2,00 & 7,00 & 4,00 & 0,91558 \\
\hline & $\mathrm{X}_{28}$ & 1,00 & 5,00 & 4,00 & 0,75284 \\
\hline & $X_{29}$ & 2,00 & 5,00 & 4,00 & 0,61431 \\
\hline & $\mathrm{X}_{210}$ & 2,00 & 5,00 & 4,00 & 0,65320 \\
\hline \multirow[t]{5}{*}{ Legitimasi Politik $\left(X_{3}\right)$} & $X_{31}$ & 2,00 & 5,00 & 5,00 & 0,65897 \\
\hline & $X_{32}$ & 2,00 & 5,00 & 4,00 & 0,82112 \\
\hline & $X_{33}$ & 2,00 & 5,00 & 4,00 & 0,86316 \\
\hline & $X_{34}$ & 1,00 & 5,00 & 4,00 & 0,83871 \\
\hline & $X_{35}$ & 1,00 & 5,00 & 5,00 & 0,65713 \\
\hline \multirow[t]{4}{*}{ Akses Informasi $\left(\mathrm{X}_{4}\right)$} & $X_{41}$ & 1,00 & 5,00 & 4,00 & 0,89188 \\
\hline & $\mathrm{X}_{42}$ & 1,00 & 5,00 & 4,00 & 0,90671 \\
\hline & $\mathrm{X}_{43}$ & 1,00 & 5,00 & 4,00 & 0,93830 \\
\hline & $\mathrm{X}_{44}$ & 1,00 & 5,00 & 5,00 & 0,95658 \\
\hline \multirow[t]{5}{*}{ Motivasi Kepala Desa $\left(\mathrm{Y}_{1}\right)$} & $\mathrm{Y}_{11}$ & 1,00 & 5,00 & 5,00 & 1,07853 \\
\hline & $\mathrm{Y}_{12}$ & 1,00 & 5,00 & 5,00 & 0,68431 \\
\hline & $Y_{13}$ & 1,00 & 5,00 & 5,00 & 0,76403 \\
\hline & $\mathrm{Y}_{14}$ & 1,00 & 5,00 & 4,00 & 0,73382 \\
\hline & $\mathrm{Y}_{15}$ & 1,00 & 5,00 & 5,00 & 0,77973 \\
\hline Partisipasi Masyarakat & $Y_{21}$ & 1,00 & 5,00 & 4,00 & 1,17103 \\
\hline \multirow[t]{3}{*}{ dalam Penganggaran $\left(\mathrm{Y}_{2}\right)$} & $\mathrm{Y}_{22}$ & 1,00 & 5,00 & 4,00 & 1,05462 \\
\hline & $\mathrm{Y}_{23}$ & 1,00 & 5,00 & 4,00 & 0,74373 \\
\hline & $\mathrm{Y}_{24}$ & 2,00 & 5,00 & 4,00 & 0,60101 \\
\hline \multirow[t]{4}{*}{ Pendapatan Asli Desa $\left(\mathrm{Y}_{3}\right)$} & $Y_{31}$ & 1,00 & 5,00 & 4,00 & 0,98939 \\
\hline & $Y_{32}$ & 1,00 & 5,00 & 4,00 & 1,10536 \\
\hline & $Y_{33}$ & 1,00 & 5,00 & 4,00 & 1,04234 \\
\hline & $\mathrm{Y}_{34}$ & 1,00 & 5,00 & 4,00 & 1,20985 \\
\hline
\end{tabular}


Tabel 3

Reliabilitas Dan Validitas Konvergen

\begin{tabular}{|c|c|c|c|c|c|c|}
\hline Variabel Laten & Indikator & $\begin{array}{l}\text { Loading } \\
\text { Faktor }\end{array}$ & $\begin{array}{l}\text { Loading } \\
\text { Faktor } 2 \\
\text { (setelah } \\
\text { di drop) }\end{array}$ & $\begin{array}{l}\text { Composite } \\
\text { Reliability }\end{array}$ & $\begin{array}{c}\text { Cronbach's } \\
\text { alpha }\end{array}$ & $\overline{\text { AVE }}$ \\
\hline \multirow{4}{*}{$\begin{array}{l}\text { Karakteristik Desa } \\
\left(\mathrm{X}_{1}\right)\end{array}$} & $\mathrm{X}_{11}$ & 0.697 & & 0.927 & 0.881 & 0.809 \\
\hline & $\mathrm{X}_{12}$ & 0.901 & 0.949 & & & \\
\hline & $\mathrm{X}_{13}$ & 0.897 & 0.881 & & & \\
\hline & $\mathrm{X}_{14}$ & 0.837 & 0.865 & & & \\
\hline \multirow{10}{*}{$\begin{array}{l}\text { Gaya Kepemimpinan } \\
\left(X_{2}\right)\end{array}$} & $X_{21}$ & 0.400 & & 0.936 & 0.917 & 0.711 \\
\hline & $X_{22}$ & 0.785 & 0.826 & & & \\
\hline & $X_{23}$ & 0.770 & 0.828 & & & \\
\hline & $X_{24}$ & 0.610 & & & & \\
\hline & $X_{25}$ & 0.795 & 0.890 & & & \\
\hline & $X_{26}$ & 0.332 & & & & \\
\hline & $X_{27}$ & 0.894 & 0.924 & & & \\
\hline & $\mathrm{X}_{28}$ & 0.779 & 0.857 & & & \\
\hline & $X_{29}$ & 0.744 & 0.720 & & & \\
\hline & $X_{210}$ & 0.162 & & & & \\
\hline \multirow{5}{*}{$\begin{array}{l}\text { Legitimasi Politik } \\
\left(\mathrm{X}_{3}\right)\end{array}$} & $X_{31}$ & 0.647 & & 0.880 & 0.727 & 0.786 \\
\hline & $X_{32}$ & 0.769 & 0.886 & & & \\
\hline & $X_{33}$ & 0.663 & & & & \\
\hline & $X_{34}$ & 0.561 & & & & \\
\hline & $X_{35}$ & 0.903 & 0.886 & & & \\
\hline \multirow[t]{4}{*}{ Akses Informasi $\left(X_{4}\right)$} & $X_{41}$ & 0.949 & 0.956 & 0.958 & 0.934 & 0.883 \\
\hline & $\mathrm{X}_{42}$ & 0.914 & 0.912 & & & \\
\hline & $X_{43}$ & 0.924 & 0.951 & & & \\
\hline & $\mathrm{X}_{44}$ & -0.441 & & & & \\
\hline Motivasi Kepala & $Y_{11}$ & 0.008 & & 0.929 & 0.898 & 0.768 \\
\hline \multirow[t]{4}{*}{ Desa $\left(Y_{1}\right)$} & $Y_{12}$ & 0.776 & 0.776 & & & \\
\hline & $Y_{13}$ & 0.880 & 0.881 & & & \\
\hline & $Y_{14}$ & 0.921 & 0.920 & & & \\
\hline & $Y_{15}$ & 0.921 & 0.920 & & & \\
\hline Partisipasi & $Y_{21}$ & 0.273 & & 0.925 & 0.878 & 0.805 \\
\hline Masyarakat dalam & $Y_{22}$ & 0.884 & 0.881 & & & \\
\hline \multirow[t]{2}{*}{ Penganggaran $\left(\mathrm{Y}_{2}\right)$} & $\mathrm{Y}_{23}$ & 0.940 & 0.935 & & & \\
\hline & $\mathrm{Y}_{24}$ & 0.849 & 0.874 & & & \\
\hline Pendapatan Asli & $Y_{31}$ & 0.712 & 0.875 & 0.868 & 0.695 & 0.766 \\
\hline \multirow[t]{3}{*}{ Desa $\left(Y_{3}\right)$} & $Y_{32}$ & 0.901 & 0.875 & & & \\
\hline & $Y_{33}$ & 0.517 & & & & \\
\hline & $Y_{34}$ & 0.165 & & & & \\
\hline
\end{tabular}

Sumber: data hasil penelitian (diolah)

Analisis Model Pengukuran (Outer Model)

Untuk pengukuran reliabilitas instrumen penelitian maka dapat dilihat dari composite reliability dan cronbach's alpha pada Tabel 3, dimana keduanya harus memiliki nilai di atas 0,70 sebagai syarat untuk memenuhi reliabilitas yang baik, tabel di atas telah menunjukkan bahwa 
reliabilitas instrument penelitian telah terpenuhi, hal ini karena nilai yang tertera telah menunjukkan hasil di atas 0,70. Sedangkan untuk pengukuran validitas konstruk dapat dilihat dari dua komponen yaitu 1) validitas konvergen, dimana dapat dilihat pada a) Loading Factor, dengan besaran nilai harus di atas 0.70, khusus untuk kuesioner yang baru dikembangkan apabila nilai loadingnya masih belum mencapai 0,70 maka nilai yang memiliki kisaran antara 0,40-0,70 harus tetap dipertimbangkan untuk dipertahankan (Sholihin dan Dwi, 2013). Berdasarkan Tabel 3 menunjukkan bahwa untuk loading factor telah memenuhi persyaratan, karena telah menunjukkan nilai di atas 0,70 dan juga nilai yang besarnya pada kisaran 0,40 sampai dengan 0,70. b) Average Variance Extracted (AVE), dimana dalam AVE nilainya harus mencapai di atas 0,50 , hal ini juga telah terpenuhi karena nilai AVE semuanya telah mencapai di atas 0,50 dan 2) Validitas diskriminan yang dapat dilihat untuk akar AVE, dalam penelitian ini pada kolom diagonal telah menunjukkan nilai yang lebih tinggi daripada korelasi antar variabel laten pada kolom selain diagonal (off diagonal).

Hal ini menunjukkan bahwa validitas diskriminan dalam model pengukuran adalah reliabel dan valid. Hasil uji validitas diskriminan selengkapnya dapat dilihat pada Tabel 4.

Tabel 4

Validitas Diskriminan

\begin{tabular}{|c|c|c|c|c|c|c|c|}
\hline Variabel Laten & $\begin{array}{l}\text { Karakteri } \\
\text { stik Desa } \\
\left(X_{1}\right)\end{array}$ & $\begin{array}{c}\text { Gaya } \\
\text { Kepemim } \\
\text { pinan }\left(X_{2}\right)\end{array}$ & $\begin{array}{l}\text { Legitima } \\
\text { si Politik } \\
\quad\left(X_{3}\right)\end{array}$ & $\begin{array}{c}\text { Akses } \\
\text { Informa } \\
\text { si }\left(X_{4}\right)\end{array}$ & $\begin{array}{c}\text { Motiva } \\
\text { si } \\
\text { Kepala } \\
\text { Desa } \\
\left(\mathrm{Y}_{1}\right) \\
\end{array}$ & $\begin{array}{c}\text { Partisipasi } \\
\text { Masyarakat } \\
\text { dalam } \\
\text { Penganggar } \\
\text { an }\left(\mathrm{Y}_{2}\right)\end{array}$ & $\begin{array}{c}\text { Pendapa } \\
\text { tan Asli } \\
\text { Desa } \\
\left(\mathrm{Y}_{3}\right)\end{array}$ \\
\hline $\begin{array}{l}\text { Karakteristik } \\
\text { Desa }\left(X_{1}\right)\end{array}$ & $(0.899)$ & & & & & & \\
\hline $\begin{array}{l}\text { Gaya } \\
\text { Kepemimpinan } \\
\left(\mathrm{X}_{2}\right) \\
\text { Legitimasi }\end{array}$ & $0.555^{*}$ & $(0.843)$ & & & & & \\
\hline $\begin{array}{l}\text { Politik }\left(X_{3}\right) \\
\text { Akses }\end{array}$ & $0.564^{*}$ & $0.864^{* * *}$ & $(0.886)$ & & & & \\
\hline $\begin{array}{l}\text { Informasi }\left(\mathrm{X}_{4}\right) \\
\text { Motivasi }\end{array}$ & $0.685^{* *}$ & 0.205 & 0.252 & $(0.940)$ & & & \\
\hline $\begin{array}{l}\text { Kepala Desa } \\
\left(\mathrm{Y}_{1}\right) \\
\text { Partisipasi } \\
\text { Masyarakat } \\
\text { dalam }\end{array}$ & -0.177 & 0.345 & 0.290 & -0.197 & $(0.876)$ & & \\
\hline $\begin{array}{l}\text { Penganggaran } \\
\left(\mathrm{Y}_{2}\right) \\
\text { Pendapatan }\end{array}$ & 0.010 & 0.137 & -0.102 & 0.073 & $0.528^{*}$ & $(0.897)$ & \\
\hline Asli Desa $\left(Y_{3}\right)$ & 0.179 & 0.206 & 0.017 & -0.139 & 0.443 & 0.434 & $(0.875)$ \\
\hline
\end{tabular}

Sumber: data hasil penelitian (diolah)

Elemen diagonal: Akar AVE,

Off diagonal : Hubungan antar konstruk

$* * *$ Signifikan $p<0.001$

**Signifikan $\mathrm{p}<0.05$

* Signifikan $\mathrm{p}<0.1$ 


\section{Analisis Model Struktural (Inner Model)}

Tahapan selanjutnya adalah melakukan analisis struktural yang meliputi pengujian kecocokan model (model fit), path coefficient, dan dalam pengujian model fit melalui tiga unsur meliputi Average Path Coefficient
(APC), Average R-Square (ARS) dan Average Varians Factor (AVIF) dengan ketentuan APC dan ARS diterima apabila p-value < 0,05 dan AVIF < 5 (Sholihin dan Dwi, 2013). Tabel 5 berikut adalah output model fit indices yang dipaparkan berdasarkan pengujian.

Tabel 5

Kecocokan Model (Model Fit)

\begin{tabular}{ccccc}
\hline \hline & Indeks & P-value & Syarat/kriteria & Keterangan \\
\hline APC & 0.309 & $\mathrm{P}<0.05$ & $\mathrm{P}<0.05$ & Diterima \\
ARS & 0.598 & $\mathrm{P}<0.002$ & $\mathrm{P}<0.05$ & Diterima \\
AVIF & 1.787 & & AVIF $<5$ & Diterima \\
\hline
\end{tabular}

Sumber: data hasil penelitian (diolah)

Berdasarkan Tabel 5 maka dapat dilihat bahwa, nilai dari APC sebesar 0.229 dengan p-value <0.001 dan ARS sebesar 0.527 dengan p-value $<0.001$ serta AVIF sebesar 2.739 dimana secara keseluruhan baik APC maupun ARS memiliki p-value $<0.001$ serta AVIF memiliki nilai <5. Sehingga berdasarkan data tersebut maka model struktural (inner model) dapat diterima, karena telah didukung oleh data.

\section{Uji Hipotesis}

Pengujian hipotesis dilakukan dengan menguji model struktural dengan melihat nilai dari R-square dan nilai dari Path Coefficient, dengan melalui signifikansi maka dapat memberikan informasi tentang hubungan antar variabel dalam penelitian. Adapun hasil dari penelitian ini dapat dilihat pada gambar 1 sebagai berikut:

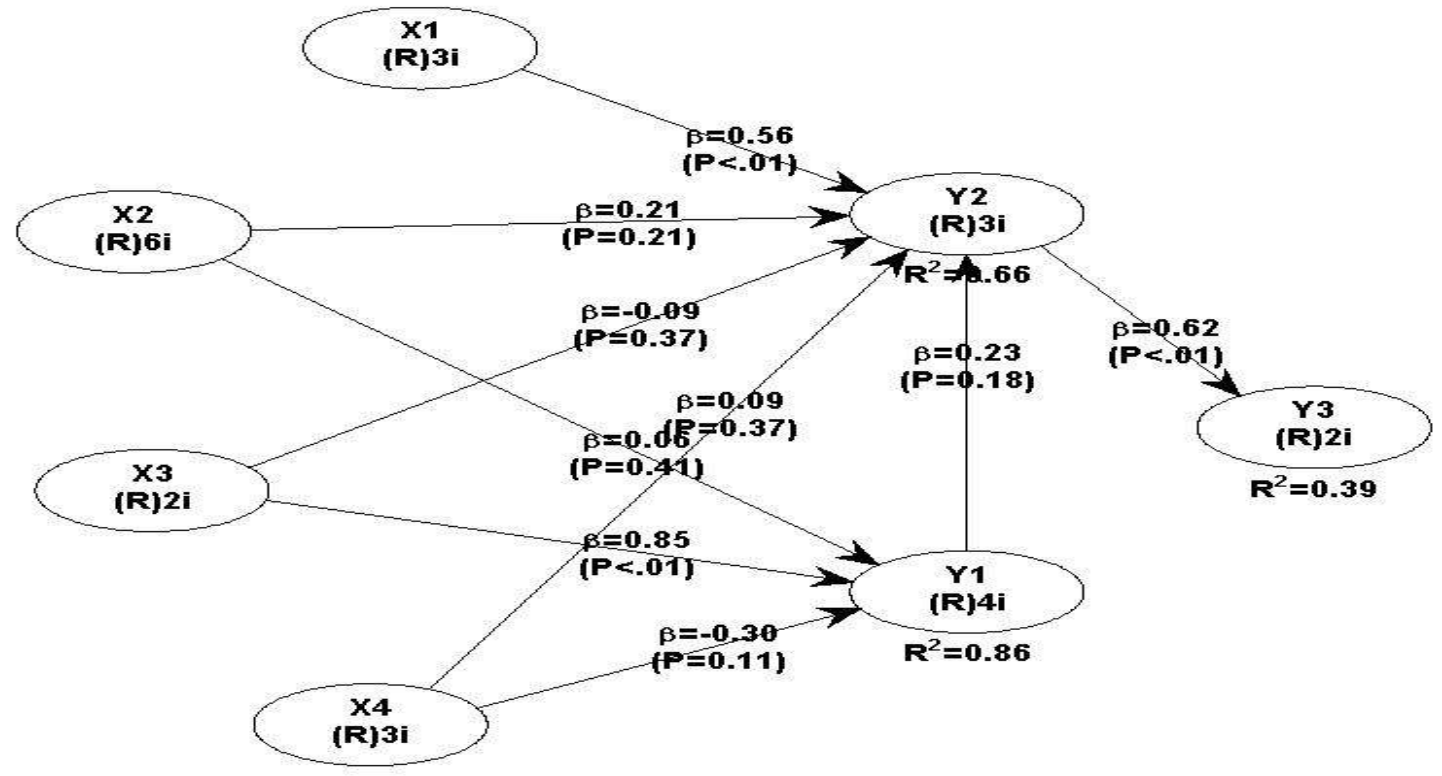

Gambar 1

Hasil Penelitian

Berdasarkan hasil penelitian di atas maka dapat dilihat adanya pengaruh hubungan langsung dengan hubungan tidak langsung antar variabel, sehingga dapat disajikan dalam Tabel 6 sebagai berikut: 
Tabel 6

Hasil Pengujian Hipotesis

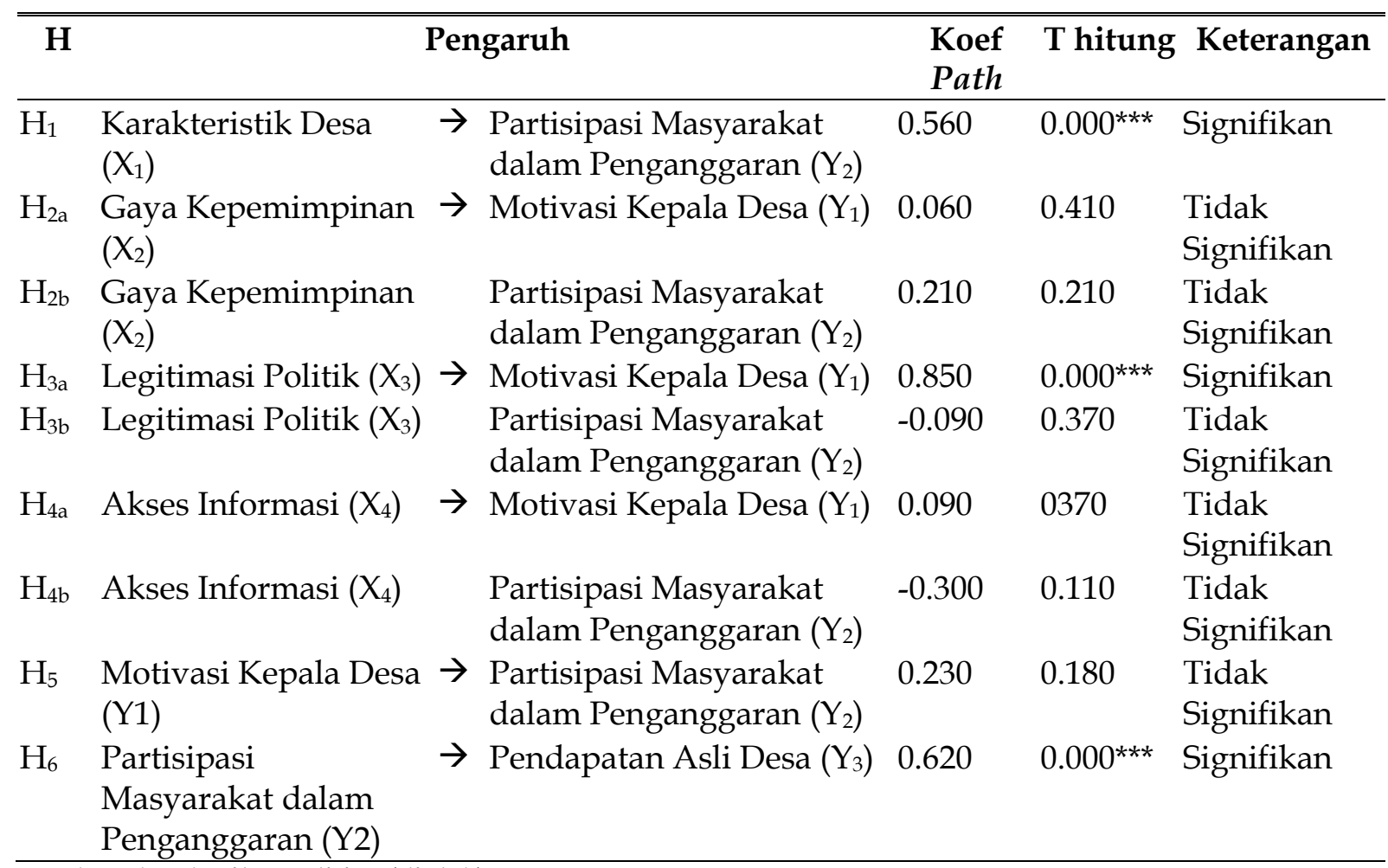

Sumber: data hasil penelitian (diolah)

$* * *$ Signifikan $\mathrm{p}<0.01$

**Signifikan $p<0.05$

* Signifikan $\mathrm{p}<0.1$

Berdasarkan hasil penelitian pada Tabel 6, maka dapat dilihat adanya pengaruh hubungan langsung dengan hubungan tidak langsung antar variabel, sehingga dapat disajikan dalam tabel sebagai berikut: Hasil pengujian hipotesis dengan membandingkan nilai $\mathrm{p}$ value dengan taraf signifikansi, jika $p$ value lebih kecil dengan taraf signifikansi maka variabel independen berpengaruh terhadap variabel dependen. Berdasarkan Tabel 6 maka persamaan strukturalnya sebagai berikut:

$\mathrm{Y}_{1}=0,060 \mathrm{X} 2+0.850 \mathrm{X} 3-0.300 \mathrm{X} 4+\mathrm{e} 1$

$\mathrm{Y}_{2}=0,560 \mathrm{X} 1+0,210 \mathrm{X} 2-0.090 \mathrm{X} 3+$ $0.850 \mathrm{X} 4+0,230 \mathrm{Y} 1+\mathrm{e} 2$

$\mathrm{Y}_{3}=0.620 \mathrm{Y} 2+\mathrm{e} 3$

Keterangan

$\mathrm{X}_{1}=$ Karakteristik Desa

$\mathrm{X}_{2}=$ Gaya Kepemimpinan

$\mathrm{X}_{3}=$ Legitimasi Politik
$\mathrm{X}_{4}=$ Akses Informasi

$\mathrm{Y}_{1}=$ Motivasi kepala desa

$\mathrm{Y}_{2}=$ Partisipasi Masyarakat dalam

Penganggaran

$\mathrm{Y}_{3}=$ Pendapatan Asli Desa

\section{Pembahasan Hasil Penelitian}

Fokus dalam penelitian ini adalah untuk menguji pengaruh karakteristik desa, gaya kepemimpinan, legitimasi politik, akses informasi terhadap pendapatan asli desa melalui motivasi kepala desa dan partisipasi masyarakat dalam penganggaran. Untuk itu akan dipaparkan pembahasan terkait hasil penelitian tentang hal tersebut, adapun pembahasannya meliputi sebagai berikut:

\footnotetext{
Pengaruh Karakteristik Desa terhadap Partisipasi Masyarakat dalam Penganggaran
} 
Berdasarkan hasil penelitian bahwa karakteristik desa mempunyai pengaruh yang signifikan terhadap partisipasi masyarakat dalam penganggaran $(\beta=0.560$ dan $p$ $<0.01)$, hal ini sesuai dengan hipotesis $\left(\mathrm{H}_{1}\right)$ yang menyatakan bahwa karakteristik desa berpengaruh terhadap partisipasi masyarakat dalam penganggaran, sehingga semakin tinggi karakteristik desa maka akan semakin meningkatkan partisipasi masyarakat dalam penganggaran. Temuan ini pula yang telah mendukung hasil penelitian dari Suroso et al. (2014) dan Eko (2012). Hasil ini menunjukkan tingkat kesadaran masyarakat untuk kemudian aktif terlibat dalam mengidentifikasi kebutuhan mendasar yang belum dipenuhi, sekaligus ikut serta dalam pengambilan keputusan publik dalam bentuk partisipasi masyarakat dalam penganggaran.

\section{Pengaruh Gaya Kepemimpinan terhadap Motivasi Kepala Desa}

Berdasarkan hasil penelitian bahwa gaya kepemimpinan mempunyai pengaruh yang tidak signifikan terhadap motivasi kepala desa $(\beta=0,060$ dan $p>0,1)$, hal ini tidak sesuai dengan hipotesis $\left(\mathrm{H}_{2 \mathrm{a}}\right)$ yang menyatakan bahwa gaya kepemimpinan berpengaruh terhadap motivasi kepala desa. Temuan ini tidak mendukung hasil penelitian dari Zhang dan Yang (2009). Hasil ini menunjukkan gaya kepemimpinan tidak memengaruhi motivasi kepala desa. Gaya kepemimpinan yang dibentuk oleh pengetahuan dan ketrampilan professional tidak memengaruhi motivasi pimpinan yang lebih besar untuk melibatkan warga.

\section{Pengaruh Gaya Kepemimpinan terhadap Partisipasi Masyarakat dalam Pengang- garan}

Berdasarkan hasil penelitian bahwa Gaya Kepemimpinan mempunyai pengaruh yang tidak signifikan terhadap partisipasi masyarakat dalam penganggaran $(\beta=0,210$ dan $\mathrm{p}>0,1)$, hal ini tidak sesuai dengan hipotesis $\left(\mathrm{H}_{2 \mathrm{~b}}\right)$ yang menyatakan bahwa gaya kepemimpinan berpengaruh terhadap partisipasi masyarakat dalam penganggaran. Temuan ini tidak mendukung hasil penelitian dari Suroso et al. (2014). Hasil penelitian ini menunjukkan gaya kepemimpinan tidak berhubungan dengan tingkat partisipasi masyarakat dalam proses perencanaan dan penganggaran (Musrembangdes). Partisipasi masyarakat dalam proses perencanaan dan penganggaran (Musrembangdes) dipengaruhi oleh kedekatan kepala desa terhadap warga

\section{Pengaruh Legitimasi Politik terhadap Motivasi Kepala Desa}

Berdasarkan hasil penelitian bahwa legitimasi politik mempunyai pengaruh yang signifikan terhadap motivasi kepala Desa $(\beta=0,850$ dan $p<0,01)$, hal ini sesuai dengan hipotesis (H3a) yang menyatakan bahwa legitimasi politik berpengaruh terhadap motivasi kepala desa, sehingga semakin tinggi legitimasi politik maka akan semakin meningkatkan motivasi kepala desa. Temuan ini pula yang telah mendukung hasil penelitian dari Liao dan Zhang (2012) dan Zhang dan Yang (2009. Dukungan (legitimasi) politik menambah motivasi kepala desa untuk merencanakan dan membangun desa.

\section{Pengaruh Legitimasi Politik terhadap Partisipasi Masyarakat dalam Pengang- garan}

Berdasarkan hasil penelitian bahwa legitimasi politik mempunyai pengaruh yang tidak signifikan terhadap partisipasi masyarakat dalam penganggaran $(\beta=-0,090$ dan $p>0,1)$, hal ini tidak sesuai dengan hipotesis $\left(\mathrm{H}_{3 \mathrm{~b}}\right)$ yang menyatakan bahwa legitimasi politik berpengaruh terhadap partisipasi masyarakat dalam penganggaran. Temuan ini tidak mendukung hasil penelitian dari Liao dan Zhang (2012) dan Zhang dan Yang (2009). Hal ini dikarenakan untuk pemilihan kepala desa tidak dibutuhkan partai politik. Untuk menjadi kepala desa cukup dengan surat pernyataan bersedia dicalonkan menjadi kepala desa yang dibuat oleh yang bersangkutan di atas 
kertas segel atau bermeterai cukup.

\section{Pengaruh Akses Informasi terhadap Motivasi Kepala Desa}

Berdasarkan hasil penelitian bahwa akses informasi mempunyai pengaruh yang tidak signifikan terhadap motivasi kepala desa $(\beta=0,090$ dan $p>0,1)$, hal ini tidak sesuai dengan hipotesis $\left(\mathrm{H}_{4 a}\right)$ yang menyatakan bahwa akses informasi berpengaruh terhadap motivasi kepala desa. Temuan ini tidak mendukung hasil penelitian dari Liao dan Zhang (2012). Hal ini terjadi karena akses informasi di desa sangat tertutup dan susah diperoleh. Masyarakat juga tidak tahu apa yang telah dilaksanakan oleh aparatur desa.

\section{Pengaruh Akses Informasi terhadap Partisipasi Masyarakat dalam Pengang- garan}

Berdasarkan hasil penelitian bahwa akses informasi mempunyai pengaruh yang tidak signifikan terhadap partisipasi masyarakat dalam penganggaran $(\beta=-0,300$ dan $p$ $>0,1)$, hal ini tidak sesuai dengan hipotesis (H4b) yang menyatakan bahwa akses informasi berpengaruh terhadap partisipasi masyarakat dalam penganggaran. Temuan ini tidak mendukung hasil penelitian dari Zhang dan Yang (2009). Sulitnya akses informasi ini menyulitkan masyarakat mengontrol penggunaan anggaran desa. Sistem pengelolaan berbasis online juga sangat jarang ditemukan di desa sehingga semua kurangnya transparannya informasi ini menyulitkan masyarakat dalam menyampaikan aspirasi untuk ditindaklanjuti pemerintah.

\section{Pengaruh Motivasi Kepala Desa terhadap Partisipasi Masyarakat dalam Pengang- garan}

Berdasarkan hasil penelitian bahwa motivasi kepala desa mempunyai pengaruh yang tidak signifikan terhadap partisipasi masyarakat dalam penganggaran $(\beta=0,230$ dan $\mathrm{p}>0,1)$, hal ini tidak sesuai dengan hipotesis (H5) yang menyatakan bahwa motivasi kepala desa berpengaruh terhadap partisipasi masyarakat dalam penganggaran. Temuan ini tidak mendukung hasil penelitian dari Zhang dan Yang (2009). Motivasi kepala desa bukan semata-mata untuk membangun desa namun lebih karena banyaknya dana yang masuk ke desa seperti dana desa, alokasi dana desa dan PAD desa.

Pengaruh Partisipasi Masyarakat dalam Penganggaran terhadap Pendapatan Asli Desa

Berdasarkan hasil penelitian bahwa partisipasi masyarakat dalam penganggaran mempunyai pengaruh yang signifikan terhadap pendapatan asli desa $(\beta=0,620$ dan $p$ $<0,01$ ), hal ini sesuai dengan hipotesis (H6) yang menyatakan bahwa partisipasi masyarakat dalam penganggaran berpengaruh terhadap pendapatan asli desa, sehingga semakin tinggi partisipasi masyarakat dalam penganggaran maka akan semakin meningkatkan pendapatan asli desa. Temuan ini pula yang telah mendukung hasil penelitian dari Leonard et al., (2010). Semakin tinggi partisipasi masyarakat untuk ikut terlibat dalam penganggaran, diharapkan akan berkontribusi positif terhadap pendapatan swadaya atau gotong royong. Selain itu disisi lain, hasil dari pendapatan swadaya, partisipasi, atau gotong royong pada dasarnya dapat dihubungkan atau mengindikasikan tingkat partisipasi masyarakat dalam proses penganggaran maupun pelaksanaan pembangunan

\section{SIMPULAN DAN SARAN Simpulan}

Berdasarkan hasil penelitian yang telah dipaparkan di atas, maka dapat ditarik kesimpulan sebagai berikut: pertama, faktor legitimasi politik berpengaruh terhadap motivasi kepala desa, karakteristik desa berpengaruh terhadap partisipasi masyarakat dalam penganggaran di desa. Faktor gaya kepemimpinan, legitimasi politik, dan akses informasi, tidak berpengaruh terhadap motivasi kepala desa. Faktor gaya 
kepemimpinan, legitimasi politik, dan akses informasi, dan motivasi kepala desa tidak berpengaruh partisipasi masyarakat dalam penganggaran di desa. Kedua, Partisipasi masyarakat dalam penganggaran berpengaruh terhadap pendapatan asli desa

\section{Keterbatasan dan Saran}

Dengan hasil penelitian yang diperoleh, disarankan bahwa; Pertama, Penelitian ini hanya menggunakan variabel yang terbatas hanya karakteristik desa, gaya kepemimpinan, legitimasi politik, dan akses informasi, sehingga dibutuhkan variabel lain agar mampu melihat secara jelas segala sesuatu atau faktor yang mampu meningkatkan partisipasi masyarakat dalam penganggaran di desa dan pendapatan asli desa. Variabel lain yang memengaruhi partisipasi masyarakat dalam penganggaran diantaranya: kinerja aparatur desa dan tingkah laku individu berhubungan erat atau ditentukan oleh ciri-ciri sosiologis seperti umur, jenis kelamin, pengetahuan, pekerjaan dan penghasilan. Kedua, Penelitian ini ruang lingkupnya hanya mencakup desa yang ada di seluruh Jawa Timur, sehingga hanya gambaran pengelolaan keuangan desa dan kinerja kepala desa yang ada seluruh Jawa Timur saja yang mampu di lihat dalam penelitian ini. Untuk penelitian selanjutnya hendaknya dilakukan di desa yang ada di seluruh Indonesia, sehingga hasil yang didapat mampu men-generalisasi untuk seluruh desa yang ada di Indonesia.

\section{DAFTAR PUSTAKA}

Ekawati, dan. N. 2012. Legitimasi Politik Pemerintah Desa (studi Pengunduran Diri kepala Desa di Desa Cindai Alus Kecamatan Martapura Kabupaten Banjar). Jurnal Ilmu Politik dan Pemerintahan Lokal I(2): 58-72.

Eko, S. 2012. Perubahan Desa di Indonesia Timur. Stock Taking Study, IRE Yogjakarta.

Fauzi, A., dan Haryanto. 2013. Anteseden Partisipasi Anggaran: Gaya Kepemimpinan, Asimetri Informasi, dan Peng- gunaan Realisasi anggaran sebagai alat evaluasi (Studi Kasus Atker di Wilayah Pembayaran KPPN Selong). Diponegoro Journal of Accounting, 2(3).

Handayani, N., Syafrudin, dan Eko, S. 2012. Transformasi Modal Sosial ke Modal Ekonomi: Pelajaran Berharga Dari Kabupaten Dompu Provinsi Nusa Tenggara Barat. Stock Taking Study, IRE Yogjakarta, 2012.

Kunwaviyah, dan Syafruddin, M. 2010. Peran Variabel Komitmen Organisasi dan Inovasi Pada Hubungan Penganggaran dan kinerja: Studi Kasus Pada Skpd Kabupaten Magelang. Jurnal Akuntansi \& Auditing 7(1): 33-48.

Leonard, T., Croson, R. T. A., dan Oliveira, A. C. M. d. 2010. Social capital and public goods. The Journal of SocioEconomics 39(2010): 474-481.

Liao, Y., dan Zhang, Y. 2012. Citizen Participation in Local Budgeting: Mechanisms, Political Support, and City Manager's Moderating Role. International Review of Public Administration 17(2): 19-38.

Mahendro, A. Y. 2013. Menggantung ke "Atas": Perkumpulan Sosial Perdesaan di Era Desentralisasi. Jurnal Sosiologi Masyarakat 18(2): 181-201.

Pratiwi, P. H. 2012. Perencanaan Partisipasi Lokal: Pengalaman Advokasi Participatory Budgeting LSM di Yogjakarta. Komunitas 4(1): 27-35.

Raghunandan, M., Ramgulam, N., dan Raghunandan, M. K. 2012. Examining the Behavioural Aspects of Budgeting with particular emphasis on Public Sector/Service Budgets. International Journal of Business and Social Science 3(14): 110-117.

Rahardjo, S. N. 2009. Pengaruh Leadership Style dan Kultur Paternalistik terhadap Efektivitas Anggaran Partisipatif Dalam Peningkatan Kinerja. Jurnal Akuntansi \& Auditing 5(2): 112-127.

Sholihin, M., dan Dwi, R. 2013. Analisa SEMPLS dengan WrapPLS 3.0 Untuk Hubungan Nonlinier Dalam Penelitian 
Sosial Dan Bisnis. Penerbit: Andi Yogyakarta.

Sugiyono. 2014. Metode Penelitian Kuantitatif, Kualitatif Dan $R \mathcal{E} D$. Alfabeta Bandung.

Sujito, A. 2013. Konteks dan Arah Pembaharuan Desa Dalam Advokasi RUU Desa. Jurnal MANDATORY 10(1): 141151.

Suroso, H., Hakim, A., dan Noor, I. 2014. Faktor-Faktor Yang Memengaruhi Partisipasi Masyarakat Dalam Perencanaan Pembangunan Di Desa Banjaran Kecamatan Driyorejo Kabupaten Gresik. Wacana 17(1): 7-15.

Valastro, A. 2012. Volunteerism, solidarity and social capital. Italian Sociological Review 2(1): 24-32.

Vincent, S. 2010. Participatory budgeting in Peru: Democratization, state control, or community autonomy? Journal of Global and Historical Anthropology 56(2010): 6577.
Wahyuningsih, S., dan Pramuka, B. A. 2012. Determinan Partisipasi Anggaran dan Pengaruhnya Terhadap Kinerja Manajerial Aparat Pemerintah Daerah Kabupaten Banyumas. Jurnal Akuntansi $\mathcal{E}$ Auditing 9(1).

Wu, Y., dan Wang, W. 2011. The Rationalization of Public Budgeting In China: A Reflection on Participatory Budgeting In Wuxi. Public Finance and Management 11(3): 262-283.

Yuen, D. 2007. Antecedents of Budgetary Participation: Enhancing Employees' Job Performance. Managerial Auditing Journal 22(5): 533-548.

Zhang, Y., dan Yang, K. 2009. Citizen Participation In The Budget Process: The Effect of City Managers. Jurnal of Public Budgeting, Accounting \& Financial Management 21(2): 289-317. 